\title{
Estimation of Insulin and Glutamic Acid Decarboxylase Autoantibodies In Patients With Type 1 Diabetes Mellitus
}

\author{
Abbas J Mohammed (BSc ,HD clinical immunity) ${ }^{1}$
}

\begin{abstract}
Background:Diabetes mellitus is a chronic disease began when there is essential insufficiency of insulin that produces by the pancreas, sometimes by the incompetence of that insulin. Such as insufficiency lead to elevate blood glucose concentrations, that in sequence impairment many human body. There are two main types of this disease, our study will be on type 1diabetes mellitus. Type 1 diabetes which called insulin-dependent diabetes mellitus in this type the pancreas be unsuccessful to produce the insulin. Typeldiabetes milltus progress commonly in children and young people, type 1 diabetes is described by presence of mixing autoantibodies against variation of insulin antigens, such as Insulin autoantibodies,Glutamic Acid Decarboxylase Autoantibodies.

Objective:To estimate the most autoantibodies and assessment of HbA1c in type $1 \mathrm{DM}$.

Patients and Methods: This study was conducted at in AL-kindy Teaching Hospital-Center of Endocrine glands and diabetes Mellitus For the period 1/7/2016 until 1/2/2017, The study included (75) individual divided into (50) diabetic patients( 25 female and 25 male) their ages ranging between 10-45 years and(25).Healthy persons (11 female and 14 male) and there was questions for each patient about( Age, Family history, Onset of diseaselyears.(Quantative ELISA test for detection of circulating autoantibodies against Glutamic Acid Decarboxylase jIndirect immunofluorescence test to detected insulin auto antibodies in human serum, and measurements level of HbA1c for each subjects.

Results: The results of this study indicate importance of autoantibodies to identify a group of type 1 diabetes mellitus patients. This results showed significant difference in the prevalence of autoantibodies in diabetes mellitus type 1 patients $(\mathrm{P}<0.05)$. There was significant association between Insulin and Glutamic Acid Decarboxylase Autoantibodies. and onset of type 1diabetes mellitus, These autoantibodies are more occurrence in earlier affected type 1 Diabetes Mellitus patients . No correlation between gender and diabetes type 1 non significant difference $(\mathrm{P}>0.05)$.

Conclusion:There are many cases of Diabetes Mellitus identified by laboratory investigation only; whom are asymptomatic, screening tests had supportive for quick detection and treatment.

Keywords: Diabetes Mellitus Type 1, Insulin autoantibodies, Glutamic acid decarboxylase, Autoimmunity.

Corresponding Author: abbasjassim79@outlook.com

Received: $24^{\text {th }}$ September 2018

Accepted: $4^{\text {th }}$ November 2018
\end{abstract}

\footnotetext{
${ }^{1}$ Diyala Health Governorate -Diyala- Iraq.
} 


\section{Introduction}

Diabetes mellitus a chronic disease related to the elevation levels of the glucose in the blood. Diabetes is caused by to one of two tools: Insufficient of insulin manufactured this caused by the pancreas and pull down of glucose in the blood and Insufficient the affinity action of insulin to the cells.

In first type of diabetes there is definitely no insulin or inadequate[1]. In second type of diabetes, there is adequately insulin but the cells should act are not delicate to its inaction[2]. Insulin this hormone which produce by beta cells of the pancreas. It is action to assisting glucose pass to cells, insulin is too essential in orginazate glucose level. Later a meal, level of glucose rises[3]. In reaction to this rises, there will be releasing of insulin to the bloodstream to assistance glucose pass in the cells and decrease glucose levels. At this time level of glucose are let down, such a controlling system benefits to save blood glucose levels in a exact value[4]. in diabetic patients, insulin is either lacking, insufficient for the body's wants, or not used appropriately by the body. These factors effect on increase levels of glucose in blood. In type 1 diabetes, immune system incorrectly productions antibodies which cause damage to body tissues. In type 1 diabetes, beta cells of the pancreas, are attacked by the immune system[5]. From these antibodies are antiinsulin antibodies (IAA)and anti-glutamic decarboxylase antibodies GADA. These antibodies are help determine which individuals are at risk for developing type 1 diabetes[6].Glutamic acid decarboxylase
(GAD) is autoantibodies involved in beta cell- autoimmunity in hereditarily predisposed persons, After GADA became obtainable, detection of GADA,IAA were advanced[7]. Studies in the relations with type 1 diabetes mellitus patients revealed that incidence of IAA, GADA by way of extra autoantibodies of IAA ,GADA at elevated concentrations is pointedly related with the HLA related- diabetes threat alleles and an total elevated threat for disease rising [8]. Even if the presence of autoantibodies is the obvious mark of developing autoimmunity of beta cell, [9] autoantibodies containing IAA ,GADA are valued in estimate and avoidance for type 1 diabetes mellitus as well as in the arrangement of autoimmune diabetes[10].

\section{Patients and Methods}

This study was carried out on 75 individual ( 50 patients and 25 control group ).patints are classified into type 1 diabetes mellitus from both sex ( 25 female and 25 male) their ages ranging between 10-45 years. All of them are insulin dependent.

Control group, 25 healthy person have been chosen in this study,from both sexes(11 females and 14 males).Descriptive variables for the patients and control was obtained during collection of blood samples including : name, sex, age, social history ,type of diabetes(only type 1 was taken) family history of diabetes (whether type 1or type 2).

Five $\mathrm{ml}$ of venous blood have been drown from each person, $2.5 \mathrm{ml}$ of blood put in 
anticoagulated tube used in measurements $\mathrm{HbA} 1 \mathrm{c}$ and other $2.5 \mathrm{ml}$ of blood put in plain

tube and centrifuged RBS or FBS tested immediately and the remaining serum was kept at -200 for further tests.Indirect immunofluorescence test to detect insulin autoantibodies(IAA) in human serum, ELISA test for detection of circulating autoantibodies against GAD antigen.

\section{Statistical analysis}

Table (1): Clinicl characteristics for Diabetes Mellitus type 1 and healthy control group.

\begin{tabular}{||l|c||c||}
\hline \multicolumn{1}{|c|}{ Variables } & Type 1DM & Control \\
\hline \hline No.(Female $\backslash$ Male) & $50(25 \backslash 25)$ & $25(11 \backslash 14)$ \\
\hline \hline Age range( mean) years & $10-45(28.4)$ & $12-48(24.7)$ \\
\hline \hline Family history(+) \% & $(6) 12 \%$ & --- \\
\hline \hline Fasting glucose $\backslash$ range( mean) mg\dl & $78-224(142.3)$ & $65-107(82.2)$ \\
\hline \hline Random glucose $\backslash$ range(mean) mg\dl & $89-410(202.5)$ & $70-141(101.8)$ \\
\hline \hline Onset of diseaselyears & $1-19$ & --- \\
\hline \hline Recent-onset diabeticlyears $\leq$ 5years & $33(66.4 \%)$ & --- \\
\hline \hline
\end{tabular}

Table (2): HbA1c levels in study groups.

\begin{tabular}{|c|c|c|c|c|c|}
\hline $\mathrm{HbA} 1 \mathrm{c} \%$ & \multicolumn{2}{|c|}{$>7 \%$} & \multicolumn{2}{|c|}{$\leq 7 \%$} & Total \\
\hline $\begin{array}{l}\text { Study } \\
\text { groups }\end{array}$ & No. & $\%$ & No. & $\%$ & \\
\hline Type 1DM & 38 & 76 & 12 & 24 & 50 \\
\hline Control & 0 & 0 & 25 & 100 & 25 \\
\hline
\end{tabular}

Table (3): Levels of HbA1c in type $1 \mathrm{DM}$ according to gender.

\begin{tabular}{|c|c|c|c|c|c|}
\hline \multirow{2}{*}{$\begin{array}{l}\text { HbAlc } \\
\text { Type1 } \\
\text { DM }\end{array}$} & \multicolumn{2}{|c|}{$>7 \%$} & \multicolumn{2}{|c|}{$\leq 7 \%$} & \multirow[t]{2}{*}{ Total } \\
\hline & No. & $\%$ & No. & $\%$ & \\
\hline Male & 21 & 55.2 & 5 & 41.7 & 26 \\
\hline Female & 17 & 44.8 & 7 & $\begin{array}{l}58.3 \\
\end{array}$ & 24 \\
\hline Total & 38 & 100 & 12 & 100 & 250 \\
\hline
\end{tabular}


Alteration in the results may be due to differ in the biological variant between individuals and may be many factors that affect in these results including social habit (exercise ,Smoking, and food habit specifically glucose producing carbohydrate).

Table (4): Percentage 0f (IAA) in study groups.

\begin{tabular}{|c|c|c|c|c|c|}
\hline Results & \multicolumn{2}{|c|}{ positive } & \multicolumn{2}{|c|}{ Negative } & \multirow[t]{2}{*}{ Total } \\
\hline $\begin{array}{l}\text { Study } \\
\text { groups }\end{array}$ & No. & $\%$ & No. & $\%$ & \\
\hline Type 1DM & 33 & 66 & 17 & 34 & 50 \\
\hline Control & 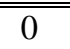 & 0 & 25 & 100 & 25 \\
\hline
\end{tabular}

Table (5): percentage of( IAA) in type $1 \mathrm{DM}$ According to the gender.

\begin{tabular}{|c|c|c|c|c|c|}
\hline $\mathrm{HbA} 1 \mathrm{c} \%$ & & & & & Total \\
\hline & No. & $\%$ & No. & $\%$ & \\
\hline Male & 18 & 54.5 & 9 & 52.9 & 27 \\
\hline Female & 15 & 45.5 & 8 & 47.1 & 23 \\
\hline Total & 33 & 100 & 17 & 100 & 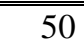 \\
\hline
\end{tabular}

Table (6): Distribution of GADA in study groups.

\begin{tabular}{|c|c|c|c|c|c|}
\hline Results & \multicolumn{2}{|c|}{ positive } & \multicolumn{2}{|c|}{ Negative } & \multirow[t]{2}{*}{ Total } \\
\hline Groups & No. & $\%$ & No. & $\%$ & \\
\hline Type 1DM & 20 & 40 & 30 & 60 & 50 \\
\hline Control & 0 & 0 & 25 & 100 & 25 \\
\hline
\end{tabular}

Table (7): Distribution GADA with type 1DM according to the gender.

\begin{tabular}{|c|c|c|c|c|c|}
\hline $\mathrm{HbA} 1 \mathrm{c}$ & \multicolumn{2}{|c|}{ Positive } & \multicolumn{2}{|c|}{ Negative } & \multirow[t]{2}{*}{ Total } \\
\hline $\begin{array}{l}\text { Type } 1 \\
\text { DM }\end{array}$ & No. & $\%$ & No. & $\%$ & \\
\hline Male & 7 & 36.9 & 18 & 58 & 25 \\
\hline Female & 12 & 63.1 & 13 & 42 & 25 \\
\hline Total & 19 & 100 & 31 & 100 & 50 \\
\hline
\end{tabular}




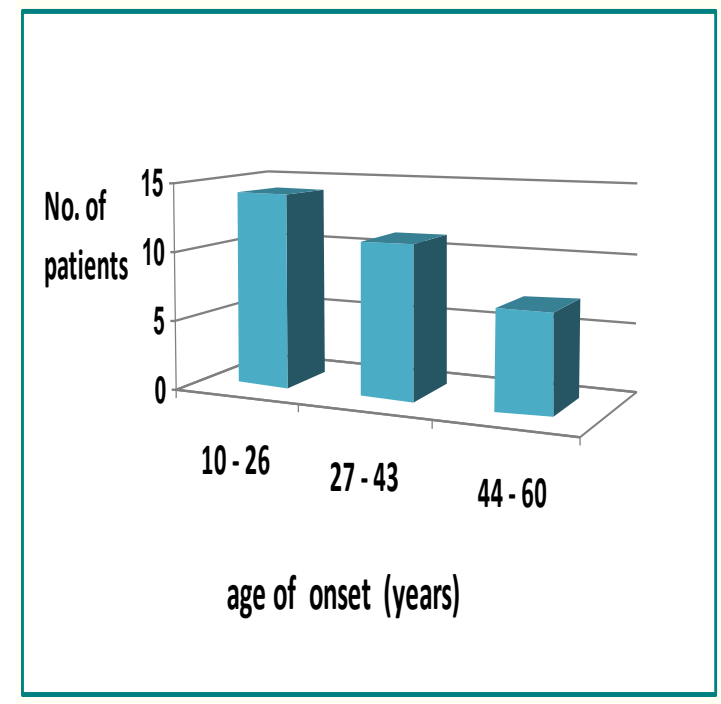

Figure(1): IAA,GAD positive distribution in relation to the age of onset in type $1 \mathrm{DM}$.

\section{Discussion}

The finest copies for diabetes type 1 at present built on joined measurement of autoantibodies[11].(IAA and GAD) are a thoughtful constituents of the grouping once looking for detect children on elevated threat of diabetes type 1 , however their lesser incidence at identification in adult persons incomes they are fewer beneficial for estimate in adolescences and adults [12]. (IAA,GAD) autoantibodies are more common in those who develop Diabetic

Mellitus type 1 in childhood and puberty[13].The initial presence of GAD, IAA are essential to subsequent the progress of autoimmunity since delivery in normal times past and main interfering lessons. Studies indicate as many patients detected with diabetes militus type 2 require flowing autoantibodies to insulin and they finally come to depend on insulin patients who are primarily not belongs to type 2 , are actually delay beginning diabetes mellitus type 1 and sometime denoted to latent autoimmune diabetes in adult [14]. Autoimmune markers such as IAA, GAD autoantibodies are identified in the patients serum several years previous to insulin dependence (Measurement of these antibodies by immunoassay) is suitable for use in routine screening for estimate \& may avoidance of diabetes in those patients[15].

The earlier phase of diabetes mellitus type 1 is characterized by the appearance of various cell antigens, the main object antigen are, Glutamic Acid Decarboxylase (GAD).Insulin Autoantibodies (IAA)[16].

Current researches have presented that detect of autoantibodies to IAA ,GAD can be of important value in the estimate, 
identification, and managing of diabetic patients [17].This study shows high significant percentage of (IAA,GAD) autoantibodies in patients with diabetes mellitus type 1 in comparison with control group $(\mathrm{P}<0.05)$, These results agree with results of another previous studies[18].

The opinion that (IAA) appear so initial with diabetes mellitus type 1 that credit epitopes of IAA perhaps be the beginning stage in the flow of autoimmune causing diabetes. an significant quantity is designed in the foundation of interference lessons using intranasal, inserted insulin, on the other hand effects of study make sure insufficient[19].There was established nearby and important association between IAA, GAD antibodies in patients of type 1DM [20].Elevated degree of GAD antibodies were determine in our results present, The detected level of GAD autoantibodies in type 1DM patients benefit in estimate the GADA advantage in this disease[21].The HbA1c test is a form of hemoglobin used to detect the average plasma glucose concentration over elongated periods of time[22].

When assessing HbA1c level in the estimate of type 1 diabetes, that perhaps assistance in initial finding and thus decrease the threat of serious problems, like ketoacidosis[23].HbA1c level is suitable important indicator to valuation the diagnosis time of diabetes mellitus type 1 with (IAA,GAD) autoantibodies[24].

\section{Conclusions}

There was a significant association between age of onset of type1 Diabetes Mellitus with Insulin and Glutamic Acid Decarboxylase Autoantibodies as insulin autoantibodies were more dominant in those affected by the disease earlier, and those autoantibodies decline and disappear with time. There was significantly greater percentage. of autoantibodies among patients with type 1 diabetes in comparison with control group ,This offers strong indication that autoimmunity plays a major role in pathogenesis of type 1 Diabetes Mellitus. References

[1] Mansson L, Torn C, Landin- Reiter J M: Islet cell antibodies represent autoimmune response in diabetes mellitus. Int $\mathbf{J}$ Exp Diabetes 2011: 85 -90.

[2]Achenbach P, Warncke K, Reiter J, Naserke HE, Williams AJ, Bingley PJ, Bonifacio E, Ziegler AG: Stratification of type 1 diabetes millitus autoantibody characteristics. Diabetes 2009: 384 -392.

[3]Naserke HE, Dozio N, Ziegler AG, Palmer JP Comparison of a novel microassay for insulin autoantibodies with the conventional radiobinding assay. Diabetologia 2010: 47:631-646. [4]Barriga KJ, Yu L, Miao D, Erlich HA, Capizzi M, Eisenbarth GS, Rewers M Measurment of insulin level in type 1 diabetes: Diabetes Autoimmunity Study in the Young (DAISY). J Clin Endocrinol Metabolism 2008: 79:3886-3900. [5] Mathis D, Vence L, Kulmala P: Beta-cell death during progression to diabetes. Nature 2011: $414: 792$ - 798. 
[6] Lounamaa R, Takino H, Yano M, Uotani S, Matsumoto K, Takao Y, Yamaguchi Y, Akazawa S, Nagataki S: Autoantibodies to glutamic acid decarboxylase in patients with IDDM and autoimmune thyroid disease. Diabetes 2012: $43: 80-86$.

[7]Törn C, Mueller PW, Schlosser M, Marshall MO, Bingley PJ Diabetes Antibody Standardization Program: evaluation of assays for autoantibodies to glutamic acid decarboxylase and islet antigen-2. Diabetologia 2008: 51:846-852. [8]Fourlanos S, Dotta F, Greenbaum CJ, Palmer JP, Rolandsson O, Colman PG, Harrison LC 2005 Latent autoimmune diabetes in adults (LADA) should be less latent. Diabetologia 2005: 48:2206-2212.

[9] Reinehr T, Schober E, Wiegand S, Thon A, Holl R , $\beta$-Cell autoantibodies in children with type 1 diabetes mellitus: subgroup or misclassification? Arch Dis Child 2006: 91:473-477.

[10]Williams R, Kellner K, Verlohren HJ, Krug J, Steindorf J, Scherbaum WA, Seissler $\mathbf{J}$ Titre and combination of IAA and autoantibodies to glutamic acid decarboxylase in clinically types Diabetes 2010: 41: 905-910.

[11]Makino H, Heine RJ, Simsek S The islet autoantibody titres: their clinical relevance in autoimmune diabetes type 1and the classification of diabetes mellitus. Diabet Med 2008: 25:117-125.

[12]Buzzetti R, Di Pietro S, Giaccari A, Petrone A, Locatelli M, Suraci C, Capizzi M, Arpi ML, Bazzigaluppi E, Dotta F, Bosi E High titer of autoantibodies to GAD identifies a specific phenotype of adult-onset autoimmune diabetes. 2007: 54: 365-372. [13] Palmer JP, Hirsch IB What's in a name: latent autoimmune diabetes of adults and puberty, type 1. adult-onset, and type 1 diabetes. Diabetes Care 2003: 26:536-538. [14]Bingley PJ, Bonifacio E, Williams AJ, Genovese S, Bottazzo GF, Gale EA Prediction of IDDM in the general population: strategies based on combinations of autoantibody markers. Diabetes 2007: 46:1701-1710.

[15]Kimpimäki T, Kupila A, Hämäläinen AM, Kukko M, Kulmala P, Savola K, Simell T, Keskinen P, Ilonen J, Simell O, Knip M The first signs of $\beta$-cell autoimmunity appear susceptible children from the general population: Type 1 Diabetes Prediction and Prevention Study. J Clin Endocrinol Metab 2001: 86:4782-4788.

[16]Johansson C, Hagopian W, Auger JA, Poumian-Ruiz E, Taylor L, Donaldson D, Gitelman SE, Harlan DM, Xu D, Zivin RA, Bluestone JA ( IAA,GADA monoclonal antibody in new-onset type 1 diabetes mellitus. N Engl J Med 2002: 346:16921698.

[17]Simsek S, Zimmet PZ, Rowley MJ, Knowles W, Mackay IR Antibodies to glutamic acid decarboxylase reveal autoimmune diabetes mellitus in adults with insulin-dependent diabetes onset of disease. Diabetes 2007 42:359-362.

[18]Fourlanos S, Perry C, Stein MS, Stankovich J, Harrison LC, Colman PG A clinical screening tool identifies autoimmune 
diabetes in adults. Diabetes Care 2006: 29:970-975.

[19]Robles DT, Tuttleman M, Srikanta S, Ganda OP, Eisenbarth GS Insulin-dependent diabetes mellitus and autoimmunity: islet cell autoantibodies, insulin autoantibodies and $\beta$ cell failure. N Engl J Med 2005: 213:734812.

[20]Emmett CL, Sanjeevi CB, Kockum I, Landin-Olsson M, Karlsen AE, Sundkvist G, Dahlquist G, Palmer J, Lernmark $\AA$ : Glutamate decarboxylase-, insulin- and islet cell-antibodies and HLA typing to detect diabetes in a general population. J Clin Invest 2007 :1435 -1490.

[21]Keskinen P, Korhonen S, Kupila A, Veijola R, Erkkila S, Savolainen H, Arvilommi P, Simell T, Ilonen J, Knip M, Simell O: First-phase insulin response in young healthy children at genetic and immunological risk for type I diabetes. Diabetologia 2002: 45 :1639-1648.

[22]Christie MR, Mackay IR, Rowley MJ, Mackay IR, Zimmet PZ, , Jensen J, Hulinsky I, Silvestrini RA, Anti-glutamate decarboxylase and insulin autoantibodies at the onset of childhood IDDM: a populationbased study. 2004: 65:124-168.

[23]Hummel M, Roll U, Payton MA, Palmer JP, Shattock M ,Validity of screening for individuals at risk for type 1 diabetes by $\mathrm{HbA1c}$ analysis to improves prediction of IDDM in islet cell antibody-positive relatives. Diabetes Care 2006: 45: 235-250. [24]Barker JM, Barriga KJ, Yu L, Miao D, Erlich HA, Norris JM, Eisenbarth GS, Rewers $M$ Biochemical markers in
Prediction of autoantibody positivity and progression to type 1 diabetes: Metab 2004 105:2680-2755. 